\title{
THE POLITICS AND GOVERNANCE OF RETAIL IN URBAN AFRICA
}

\author{
Danielle Resnick
}

Rapid urbanization in Africa south of the Sahara continues to highlight the importance of informal retailers as a source of both food and employment for the urban poor. The most recent Africa Agriculture Status Report emphasizes that, due to demographic and socioeconomic transformation in the region, the center of gravity of Africa's food system is shifting to urban areas (AGRA, 2020). Informal retailers-including those who vend in open-air wet markets and hawk on pavements and streets-provide a critical link between agricultural producers and consumers. While the COVID-19 pandemic has dramatically highlighted the vulnerability of this constituency (Resnick et al., 2020), informal traders have long been victims of other public health, economic, and climate shocks (Battersby \& Watson, 2019). To build the resilience of informal traders and enhance their contributions to urban food security, fundamental governance issues need to be addressed.

This brief synthesizes research on informal traders conducted under the "Economywide Factors Affecting Agricultural Growth and Rural Transformation" flagship of the CGIAR Research Program on Policies, Institutions, and Markets (PIM) led by IFPRI. The research spanned Ghana, Nigeria, Senegal, and Zambia and involved comparative analysis across capital cities based on media events data, surveys with traders, and interviews with urban bureaucrats. In this way, traders' experiences could be complemented with policymakers' insights about bottlenecks and opportunities for reform.

\section{KEY FINDINGS}

- Informal food retailers are an extremely diverse group who operate under varying tax, regulatory, and food safety regimes.

- Due to a lack of urban food policies, informal food retailers must navigate complex institutional and legal environments where regulations are enforced erratically.

Capacity constraints in city governments for food safety inspectors and service providers often undermine the implementation of food safety regulations. Consequently, substandard water, sanitation, and waste collection is a common challenge in markets across cities.

- Informal traders encounter many different taxes levied by city governments and other types of actors. Higher concentrations of revenue officers and better provision of services tend to be associated with higher tax compliance.

- Traders who are more satisfied with the services they receive have higher trust in their city governments.

- Partisan politics permeates informal trade in various ways, including how market stalls are allocated and the frequency of crackdowns on street vendors. 


\section{Who are traders?}

Traders' social and demographic profiles are very diverse when compared across different cities. Ghanaian cities revealed a higher share of female traders and of older traders (Table 1). At the same time, Ghana's traders are less likely to have completed secondary education or obtained a post-secondary qualification than their counterparts in Nigeria and Zambia. More traders are likely to be migrants in capital cities (Accra and Lusaka) than in smaller cities. For more than 70 percent of food traders in Ghanaian and Nigerian cities, at least one of their parents was a trader, which suggests that working in the informal economy is not always just a coping strategy but often a family tradition.

Outside of Accra, participation in traders' associations is relatively low across cities. Since membership in such associations may facilitate interaction with, and concessions from, local governments (Lindell, 2010), this variation in associational activity can have implications for the goods and services that traders in different cities are able to gain from public authorities.

Table 1: Comparison of trader profiles across African cities

\begin{tabular}{|c|c|c|c|c|c|c|}
\hline \multirow[t]{2}{*}{ Indicators } & \multicolumn{3}{|c|}{ Ghana } & \multicolumn{2}{|l|}{ Nigeria } & \multirow{2}{*}{$\begin{array}{l}\text { Zambia } \\
\text { Lusaka }\end{array}$} \\
\hline & Accra & Kumasi & Tamale & Calabar & Minna & \\
\hline \multicolumn{7}{|l|}{ Share in age group } \\
\hline $18-34$ & 28.4 & 26.2 & 33.5 & 43.3 & 40.7 & 45.5 \\
\hline $35-44$ & 31.9 & 33.1 & 24.6 & 34.5 & 36.0 & 26.6 \\
\hline 45 and older & 38.1 & 38.6 & 31.5 & 22.1 & 23.2 & 23.2 \\
\hline $\begin{array}{l}\text { Secondary education completed, } \\
\text { or post-secondary qualification } \\
\text { obtained }\end{array}$ & 21.4 & 15.4 & 9.7 & 74.0 & 51.4 & 36.2 \\
\hline Female & 94.5 & 90.9 & 84.1 & 64.7 & 35.1 & 45.3 \\
\hline Member of traders' association & 18.7 & 9.8 & 5.0 & 2.1 & 4.6 & 5.3 \\
\hline $\begin{array}{l}\text { Share who pay taxes to local gov- } \\
\text { ernment }\end{array}$ & 85.0 & 59.0 & 35.2 & 73.9 & 87.4 & 80.8 \\
\hline Migrant & 57.3 & 43.6 & 20.3 & 54.9 & 32.3 & 52.0 \\
\hline $\begin{array}{l}\text { Experienced harassment for trad- } \\
\text { ing }\end{array}$ & 25.1 & 41.4 & 26.3 & 18.3 & 3.2 & $\mathrm{~N} / \mathrm{A}$ \\
\hline Parent was a trader & 82.8 & 75.6 & 85.1 & 80.8 & 77.3 & $\mathrm{~N} / \mathrm{A}$ \\
\hline Number of observations & 453 & 456 & 300 & 530 & 567 & 813 \\
\hline
\end{tabular}

Sources: Compiled from Resnick, Sivasubramanian et al. (2019), Resnick and Sivasubramanian (2020), and Resnick (forthcoming). Notes: The Zambian survey focused on all informal traders—of whom food vendors were the majority — while those in Ghana and Nigeria specifically targeted only food vendors. N/A means the question was not asked.

\section{Complex institutional governance}

One of the main challenges for traders is that they are governed by a complex array of institutions and regulations that can be difficult to understand. In many cases, responsibilities for oversight for siting markets, collecting revenues, providing food safety licenses, and upgrading services fall to different departments of city governments. At the same time, regulations may emanate from different national ministries and agencies and not necessarily wellcommunicated to traders by local authorities (Figure 1).

Nigeria's federal structure creates additional complexities. Cities there are often an amalgamation of local government areas (LGAs) that collect revenues and issue operational permits to food vendors. However, the states have the autonomy to implement their own laws governing vending, and state 
ministries of health, agriculture, transport, and environment may all be involved in regulating traders' activities; state police and security forces monitor adherence to restrictions over public space.

In Ghana, the formal structures created by the government also overlap with other types of authority, including "market queens" who control the distribution of particular commodities, resolve disputes, manage credit relations, and provide assistance during crisis events. In Zambia, some markets are run by the city councils while others are overseen by market cooperatives. The latter largely collect fees and provide services but may need to remit property taxes to the city council for land use.

\section{Figure 1: Institutional landscape for informal food trade in Ghana's metropolitan assemblies}

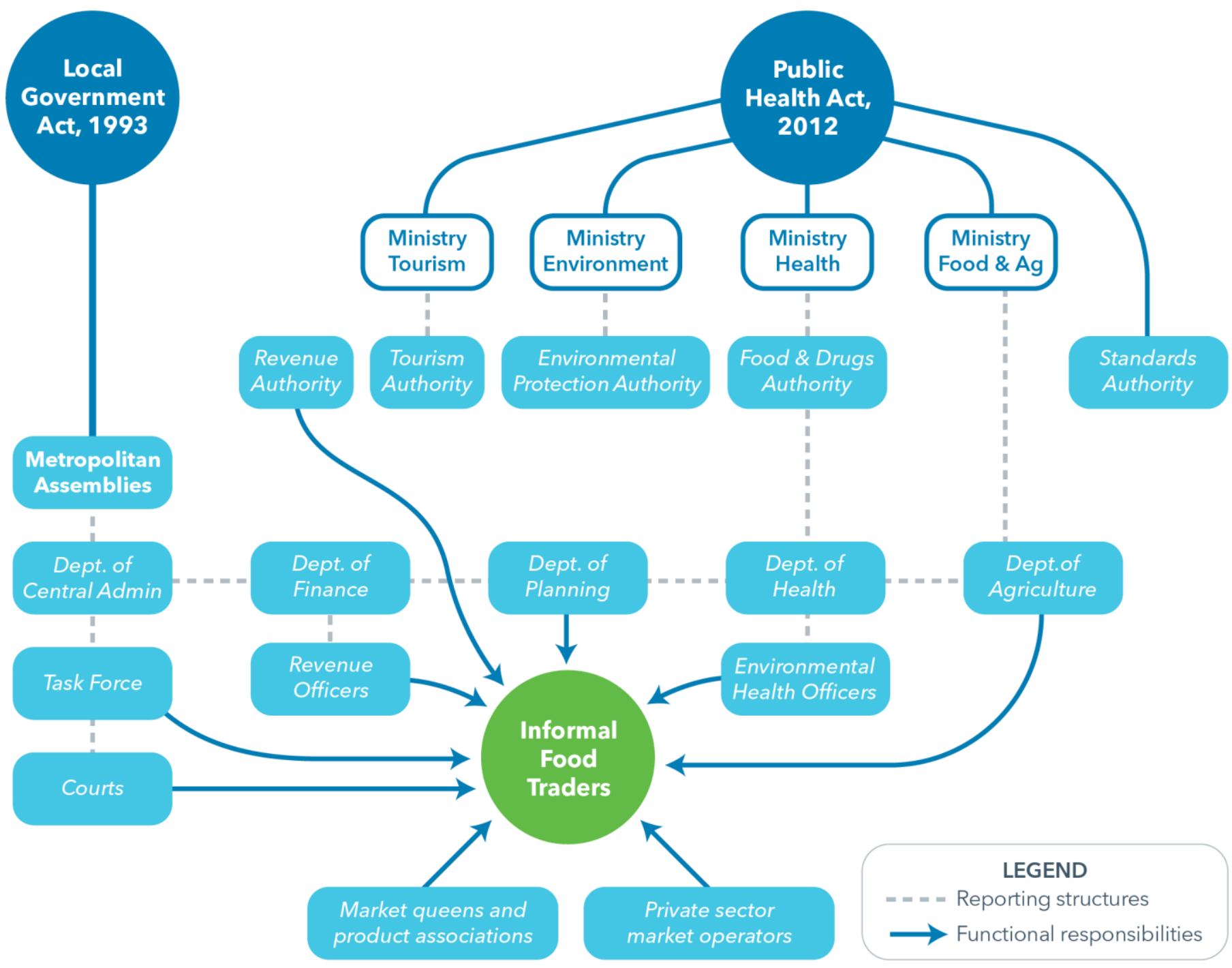

Source: Resnick and Sivasubramanian (2020)

\section{Food safety oversight and services}

These complexities in governance are meaningful for the types of water and sanitation services provided within the markets and the enforcement of food safety regulations.
Food safety hazards are widespread in Africa's informal markets (Roesel \& Grace, 2014), even though many countries have food safety regulations. These include Ghana's 2012 Public Health Act, Zambia's 2019 Food Safety Act, and state-level food safety laws in Nigeria. The implementation of 
such regulations though is often left to city governments that are severely constrained in financial and human resources. For example, in Kumasi, there is only one environmental health officer-the bureaucrat responsible for engaging in market surveillance of foods-for every 1,278 vendors (Resnick \& Sivasubramanian, 2020). In Calabar and Minna, only 6.4 and 4.4 percent of traders, respectively, interact with a local government health officer on a monthly basis (Resnick, Sivasubramanian, et al., 2019).

Insufficient services are the main barrier to improved food safety. Access to clean, running water was reported by only 17 percent of those in Calabar and 9 percent in Minna; in both cities, less than 45 percent of traders reported access to regular trash collection (Resnick, Sivasubramanian, et al., 2019). In Ghanaian cities, drainage and garbage collection were identified as traders' top two priority concerns (Resnick \& Sivasubramanian, 2020). In Lusaka, less than half of sampled traders reported having access to waste services and only 21 percent worked in a market with proper drainage during the rainy season (Resnick, forthcoming). Stagnant water that comingles with uncollected trash contributes to the regular outbreak of water-borne diseases in the capital city.

Low access to key services can be attributed to multiple factors. First, only a small portion of the revenue collected from markets goes back into markets, and the remainder goes to city coffers to fund broader services. Second, efforts to raise rates among city residents for services that benefit vendors can be met with resistance by wealthier residents who shop at more established supermarkets. Third, city governments may outsource the collection of waste to private contractors and communitybased organizations that have dramatically different capacities, equipment, and incentives. In Zambia, the problem is exacerbated by the heavy presence of political party "cadres," or vigilantes for the ruling party, who try to gain garbage contracts. As noted by market traders in Zambia's third largest city, Ndola, "As you can see outside, garbage has piled and remains uncollected for close to three weeks now. We always contribute money towards garbage collection in this market, but the private waste collectors hired by cadres complain of not being paid on time. As a result, garbage is not collected on regular basis" (cited in Resnick, Siame, et al., 2019).

\section{Taxation, trust, and accountability}

Although informality is often equated with tax evasion, most informal retailers do pay a host of market and licensing fees to their local governments (see Table 1), along with user charges to access toilets and storage facilities. Their informality derives more from their lack of access to formal social protections (including pensions and healthcare) and their lack of registration with certified business authorities. At the same time, within marketplaces, formal businesses may operate among informal traders or employ street hawkers to distribute their goods to consumers along roads and pavements. Street hawkers and those without a stall or store typically pay a relatively low daily operating fee while those who are more established encounter larger levies.

However, compliance varies substantially across cities (see Table 1). In Lusaka, for instance, compliance with taxes is relatively equal across council and cooperative markets. However, analysis shows that the drivers of compliance are quite different. In council-run markets, proximity to the central business district is a major driver of compliance while in cooperative ones, the level of service provision appears to influence compliance. Resnick

(forthcoming) argues that this discrepancy is because council markets rely on a small number of revenue officers to collect fees, and the city's constrained human resources are therefore targeted at

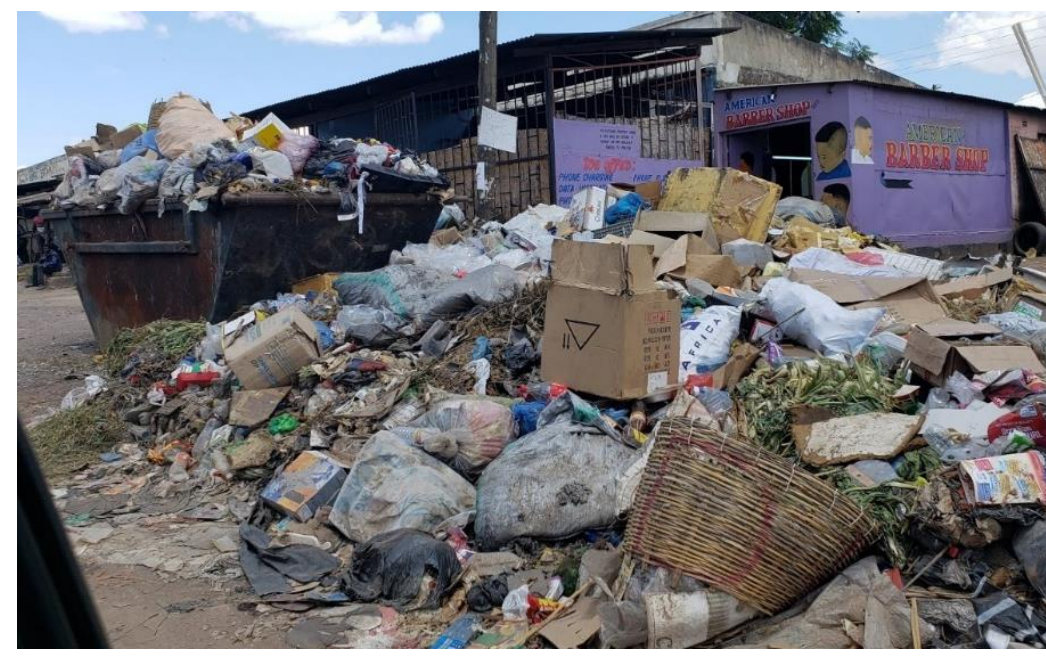

Insufficient city capacity for waste collection is a major hazard for Lusaka's markets 
markets in the city center. By contrast, in cooperative markets, traders have a much closer relationship with market leaders, who are the main revenue collectors. Where services are better, traders have more trust that the cooperative leaders are using their money appropriately and are more willing to continue paying. In other words, the drivers of compliance vary depending on the routes of accountability between taxpayers, revenue collectors, and service providers.

The transfer of benefits in return for paying taxes can also enhance trust among traders. In Ghanaian cities, those traders who pay their taxes and can identify a benefit in return are more likely to trust their local governments. This dynamic is most pronounced in Accra; trust in the capital's metropolitan assembly increases from 35 to 69 percent for a trader who can attribute some service benefit received in return for their fee payments compared to a trader in the city who does not (Resnick \& Sivasubramanian, 2020).

\section{Politics and public space}

Informal vendors frequently are involved in disputes with local governments over rights to public space. For those in established markets, upgrading initiatives may force traders to relocate to inconvenient sites that are far from their established supplier and customer base as markets are refurbished or redesigned to reduce the number of vendors (Battersby \& Muwowo, 2019). The new stalls that emerge in upgraded markets may be too expensive for the poorest traders, pushing them into street hawking.

Yet, street hawkers in African cities typically face stringent regulations that impede their operations. For instance, in Zambia, the Ministry of Local Government issued Statutory Instrument No.10 in 2018, which delineates fines for working as a hawker in the same area for more than five days in a month and for selling food in any street or public place other than a market. In Ghanaian cities, local assemblies can pass by-laws that prohibit selling goods outside of markets. While regulations are stringent in many parts of Nigeria, the city of Calabar is an exception; in 2016, the governor of Cross River, where the city is located, passed a Hawkers' Rights Protection Bill that legalizes street hawking.
Since traders are a sizable electoral constituency, they are less likely to face harassment in electoral years. However, outside of election years, other dynamics affect whether they are pushed off the streets by local authorities. An analysis of violence toward vendors in cities in Ghana, Senegal, and Zambia between 2000 and 2016 revealed that three variables play a role: political decentralization (mayors are elected rather than appointed), administrative decentralization (cities have a mandate over informal vending), and the importance of vendors to political parties at the national and municipal levels (Resnick, 2019). In Ghana, where mayors are appointed and the cities have greater autonomy over vending and markets, there have been consistent crackdowns on their activities over time and across political parties. In Senegal, where mayors are elected and have discretion over vending through the 1996 Decentralization Laws, crackdowns on vendors became more intense under mayors who derived their political support from more affluent voters. In Zambia, mayors are elected but the national government largely makes rules over informal vending; when a political party that draws support from this constituency has been in office at both levels, crackdowns on traders have been less intense.

Besides the regulation of public space, politics can permeate the market in other ways. In Accra, market associations may be affiliated with a particular party and stall allocations can depend on partisanship. In Lusaka, the party cadres mentioned above often set up offices within the largest and most lucrative markets. There, they charge a weekly operations fee and rent for trading space in the market, as well as off-loading fees of US\$3-4 per load of agricultural products brought to traders from farmers. In exchange, they promise to provide security and access to prime trading spaces. Such extortionary fees, which are levied on top of traders' payments to the city council or cooperative, mean traders pay multiple times for the same services (Resnick, forthcoming). 


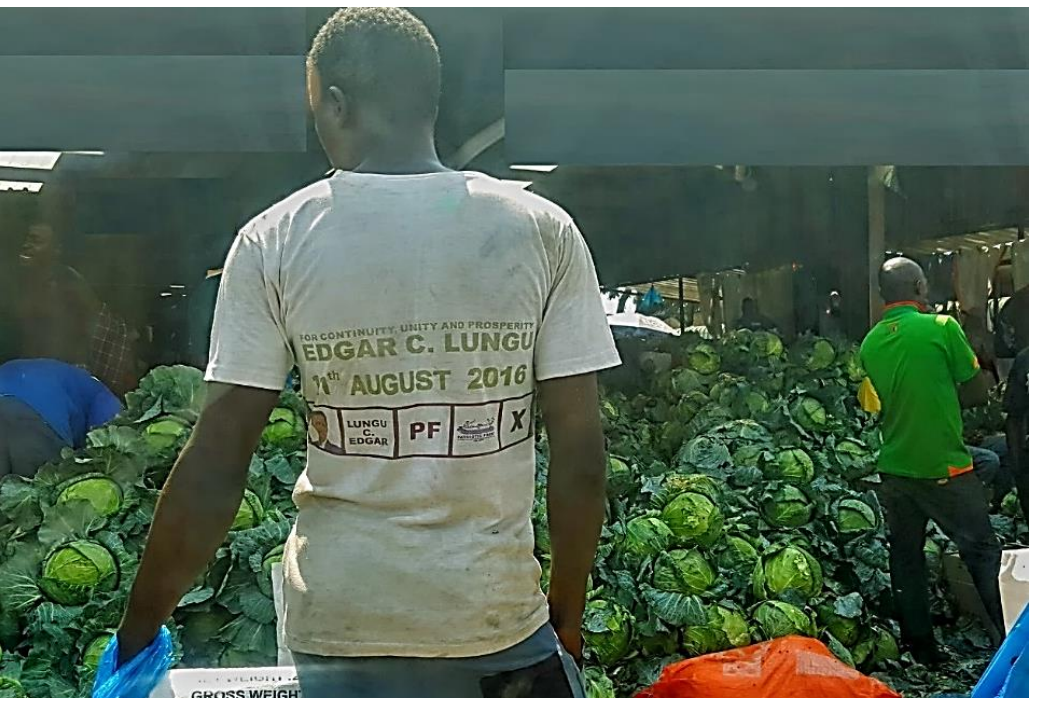

Party cadre for the Patriotic Front (PF) oversees market transactions in Lusaka

\section{Conclusions}

Informal food traders play a critical role in urban food systems and will continue to do so as Africa's cities rapidly expand. Yet, their potential to better service their customers, many of whom are low-income, is dependent on addressing major governance and political bottlenecks. This includes the complex institutional environment in which they operate, which undermines transparency and accountability for decisions by city governments. Low resource and human capacities within some cities affect consistent implementation of rules and regulations, which creates further confusion among traders about allowable and prohibited activities. Even though markets are often a key source of revenue for local governments, substandard service provision erodes traders' trust in city authorities and has negative implications for food safety. Forced relocation efforts to improve infrastructure too often ignore that traders' livelihoods have been established within a spatially concentrated web of relations with suppliers, distributors, and loyal customers.

\section{Synthesizing from this PIM research, several pol-}

icy issues emerge. First, and as noted elsewhere (Battersby \& Watson, 2019), many African cities lack comprehensive urban food policies. Designing such policies and considering their implications for land-use planning, infrastructure investment, regulation, and human resources would provide a useful focal point for different municipal and metropolitan departments to see how their disparate mandates can contribute to a holistic agenda.

\section{Second, transparency in the collection of reve- nues from markets and street hawkers is essen-} tial. Many traders do not know how their money is used or even if revenue officers remit their funds to the government. Some African countries already allow mobile payments for taxation (Ahmad et al., 2020), and this can be extended to remitting local government revenues. In Zambia, there have been ongoing efforts to use mobile payments among market traders to improve the mobilization and efficiency of revenue collection. Beyond drawing on technology, clear earmarking of revenues for re-investment into market services is another approach that may have positive externalities on tax compliance. In Guinea, for example, earmarking by the local government of market taxes to build better market facilities subsequently increased the collection of those taxes (Korsun \& Meagher, 2004).

Third, city governments, civil society groups, and traders' associations should work to create entry points for traders into urban policymaking processes relevant to their livelihoods. One option is through legal advocacy to help street vendors better understand their legal environments and how city restrictions on vending can contradict provisions within national constitutions that aim to protect workers' rights (Bamhu, 2019). Another approach involves fostering formal contracts between cities and traders; for example, in Monrovia, Liberia, the mayor engaged in regular dialogue with traders that culminated in a Memorandum of Understanding to regularize street vending and reduce harassment of traders (Reed \& Bird, 2019). Traders' scorecards that map service provision deficiencies can further assist authorities to prioritize scarce resources for investment within different markets.

Many international initiatives are giving greater attention to the role of cities in bolstering food security, including the United Nations' New Urban Agenda and Milan Urban Food Policy Pact, which thus far has been signed by mayors of 27 African cities. ${ }^{1}$ Such initiatives aim to improve rural-urban 
linkages, enhance nutrition outcomes, and address environmental sustainability. Yet, as this PIM research on urban traders highlights, the feasibility of attaining these objectives will depend on greater understanding of how food systems intersect with cities' institutional structures and political dynamics.

\section{ABOUT THE AUTHOR}

Danielle Resnick is a Senior Research Fellow in the Development Strategy and Governance Division at the International Food Policy Research Institute (IFPRI) and leader of the Political Economy and Policy Processes research cluster in the CGIAR Research Program on Policies, Institutions, and Markets (PIM).

\section{ACKNOWLEDGMENTS}

Research summarized in this brief has been undertaken as part of the CGIAR Research Program on Policies, Institutions, and Markets (PIM) led by IFPRI and supported by the CGIAR Trust Fund and through bilateral funding agreements.

\section{REFERENCES}

AGRA. (2020). Feeding Africa's Cities: Opportunities, Challenges, and Policies for Linking African Farmers with Growing Urban Food Markets. Alliance for a Green Revolution in Africa (AGRA).

Ahmad, A. H., Green, C., \& Jiang, F. (2020). Mobile Money, Financial Inclusion, and Development: A Review with Reference to African Experience. Journal of Economic Surveys, 34(4), 753-792.

Bamhu, P. (2019). Street Vendors and Legal Advocacy: Reflections from Ghana, India, Peru, South Africa, and Thailand. WIEGO Resource Document No. 14.

Battersby, J., \& Muwowo, F. (2019). Planning and governance of food systems in Kitwe, Zambia: a case study of food retail space. In J. Battersby \& V. Watson (Eds.), Urban Food Systems Governance and Poverty in African Cities (pp. 128-140). Routledge.

Battersby, J., \& Watson, V. (2019). Introduction. In J. Battersby \& V. Watson (Eds.), Urban Food Systems Governance and Poverty in African Cities. Routledge.

Korsun, G., \& Meagher, P. (2004). Failure by design? Fiscal decentralization in West Africa. In M. Kimenyi \& P. Meagher (Eds.), Devolution and development: Governance prospects in decentralizing states (pp. 137-195). Routledge.

Lindell, I. (2010). Africa's informal workers. Collective agency, alliances and transnational organizing in urban Africa. Zed Books.
Reed, S., \& Bird, M. (2019). Liberia's Street Vendors Pioneer New Approach with City Officials. WIEGO blog.

Resnick, D. (forthcoming). Taxing Informality: Compliance and Policy Preferences in Urban Zambia. Journal of Development Studies.

Resnick, D. (2019). The Politics of Crackdowns on Africa's Informal Vendors. Comparative Politics, 52(1), 21-51.

Resnick, D., Siame, G., Mulambia, P., Ndhlovu, D., Shicilenge, B., \& Sivasubramanian, B. (2019). Deepening Decentralization in Zambia Political Economy Constraints and Opportunities for Reform. IFPRI Discussion Paper.

Resnick, D., \& Sivasubramanian, B. (2020). Negotiating the social contract in urban Africa: Informal food traders in Ghanaian cities. IFPRI Discussion Paper.

Resnick, D., Sivasubramanian, B., Idiong, I. C., Ojo, M. A., \& Tanko, L. (2019). The Enabling Environment for Informal Food Traders in Nigeria's Secondary Cities. Urban Forum, 30(4), 385405.

Resnick, D., Spencer, E., \& Siwale, T. (2020). Informal traders and COVID-19 in Africa: An opportunity to strengthen the social contract. IGC Policy Brief (August).

Roesel, K., \& Grace, D. (2014). Food Safety and Informal Markets: Animal Products in Sub-Saharan Africa. Routledge.

This publication has been prepared as an output of the CGIAR Research Program on Policies, Institutions, and Markets (PIM) led by IFPRI and has not been independently peer reviewed. Any opinions expressed here belong to the author(s) and are not necessarily representative of or endorsed by IFPRI, PIM, or CGIAR.

\section{CGIAR RESEARCH PROGRAM ON POLICIES, INSTITUTIONS, AND MARKETS}

